\title{
Az egészségügyi hackathonokban rejló társadalmi értékek hazai kiaknázásának lehetőségei
}

\author{
Opportunities for Reaping the Collective Benefits of a Health-themed Hackathon in Hungary
}

\author{
Varga Gergely, Tóth Dóra, Dr. Mikesy Gergely, Makai Marianna, Joó Tamás \\ Semmelweis Egyetem Egészségügyi Menendzserképző Központ
}

A hackathon intenzív, idöben behatárolt munkát igénylő, egy előre megfogalmazott problémára innovatív megoldást kereső csapatverseny. Az „Oltáskampány Te hogy csinálnád?" címü hackathont online rendezte meg a Magyar Egészségügyi Menedzsment Társaság (MEMT), és a Semmelweis Egyetem Egészségügyi Menedzserképző Központ (EMK), a Magyar Tudományos Akadémia Fenntartható Fejlődés Elnöki Bizottsága, az Egészségügyi Világszervezet és az Innovációs és Technológiai Minisztérium támogatásával 2021. december 10. és 11. között. A platózó oltási hajlandóságot látva célként multidiszciplináris megközelítésü, innovatív, a COVID-19 oltási hajlandóságot növelő stratégiák kidolgozása lett kitüzve. A versenyen 25 négyfős, egyetemistákból álló csapat vett részt. A versenyzők munkáját szakértő előadók, valamint a megadott időpontokban mentorok segítették, akik különböző, a versenyzők projektjei szempontjából releváns területek szakértői. A hackathon teljesítette előzetesen kitüzött céljait: számos olyan ötlet gyült össze, amelyek hozzájárulhatnak a COVID-19 oltási hajlandóság növeléséhez. Továbbá, az esemény képes volt megmozgatni különböző hátterü embereket, így elősegítve az innovatív gondolkodást és multidiszciplináris problémamegoldást az egészségügy területén. Végül, figyelembe véve, hogy a vakcinák kiemelten fontos eszközei a fertőző betegségek elleni védekezésnek, tehát kiemelt egészségbiztonsági jelentőséggel bírnak, az itt bemutatott hackathon arra is rámutatott, hogy a metodológia jól alkalmazható egészségbiztonsági kockázatok kezeléséhez szükséges stratégiák generálásához. Így a hackathonok hozzájárulhatnak egy rugalmas, a jövő kihívásaira hatékonyan válaszolni képes magyar egészségügyhöz.

A hackathon is a form of competition that requires intensive effort, where teams look for an innovative solution to a pre-defined problem in a limited timeframe. "A Vaccination Campaign - How Would You Do It?" was a virtual hackathon organised on the 10th-11th December 2021 by the Hungarian Healthcare Management Association (HUHMA) and the Faculty of Health and Public Administration (EMK) of Semmelweis University (Budapest), with the support of the Committee on Sustainable Development of the Hungarian Academy of Sciences, the World Health Organisation and the
Hungarian Ministry of Innovation and Technology. The hackathon was held in Hungarian. Seeing the plateauing vaccine uptake, its goal was to encourage new, innovative, multidisciplinary strategies to increase the willingness to take COVID-19 vaccines in the population. 25 teams of 4 students participated in the competition. Expert speakers and - at indicated times - mentors from relevant fields helped the teams in the framework of short consultations. The hackathon achieved its goals: numerous ideas have been generated that could potentially contribute to an increase in the uptake of COVID19 vaccines. Moreover, the event could mobilise students from different disciplines, thereby facilitating innovative thinking and multidisciplinary approaches to problem-solving in the field of health. Finally, considering that vaccines are crucial tools in the fight against infectious diseases (and thus, they are of great importance from a health security standpoint), the hackathon described here has shown that this methodology can be successfully applied to address health security risks. Therefore, hackathons may contribute to a resilient Hungarian healthcare system that is able to effectively respond to future challenges.

\section{BEVEZETÉS}

Amikor egy összetett társadalmi problémával állunk szemben, a megoldást jelentő innovatív ötlet gyakran nem a merev döntéshozói hierarchia valamelyik szintjéről pattan ki, hanem olyan emberek fejéből, akiknek érintettsége, önálló látásmódja és proaktivitása egyedi nézőpontot biztosít számukra. A napjainkat meghatározó társadalmi probléma - a COVID-19 járvány, és az azzal összefüggő platózó oltási hajlandóság - legyőzése érdekében tehát az ilyen egyedi nézőpontok mobilizálására van szükség egy közösségi térben. Erre szolgálhat egy hackathon. Az esemény beszédes neve az angol "hack" ([egy enigma] feltörése) és „marathon” (mint koncentrált erőkifejtés) szavakból tevődik össze, utalva a hackathon két legfőbb jellegzetességére: innovatív problémamegoldás, és intenzív, időben behatárolt munka [1]. Az informatika területéről induló metodológia egyre szélesebb körű használatát jól mutatja, hogy a szakirodalomban egyre nő az egészségügyi területen rendezett hackathonokkal foglalkozó cikkek száma [2]. Alább ezek áttekintésével, és egy 
magyar egészségügyi hackathon bemutatásával szeretnénk illusztrálni a megközelítésben rejlő lehetőségeket.

\section{EGÉSZSÉGÜGYI HACKATHONOK A SZAKIRODALOMBAN}

Az amerikai Library of Medicine (PubMed) 44 olyan cikket tartalmaz, amelynek címében vagy absztraktjában szerepelnek a „Hackathon”, illetve a „Health” kifejezések, valamint a Hackathon nem csupán említésre kerül. (Az első ilyen cikket 2014-ben adták ki.) [2]. Az 1. táblázat illusztrálja a megközelítésekben jelentkező diverzitást, amelyben alapvetően két változót azonosíthatunk: (1) a hackathon melyik aspektusát dolgozza fel a cikk (szervezés, lebonyolítás, eredmények), illetve (2) hogy egy adott eseményre fókuszál, vagy tágabb perspektívát vesz fel. Itt érdemes kiemelni, hogy - ahogy azt az 1. táblázat is jól szemlélteti - a hackathonokkal foglalkozó munkák túlnyomó többsége egy adott eseményt bemutató esettanulmány.

\begin{tabular}{|c|c|c|c|}
\hline & & Esettanulmány & Nem esettanulmány \\
\hline \multicolumn{2}{|l|}{ Szervezés } & 6 & 9 \\
\hline \multirow[t]{2}{*}{ Eredmények } & Termékek & 4 & 2 \\
\hline & $\begin{array}{l}\text { Haszon a résztvevők } \\
\text { szemszögéből }\end{array}$ & 5 & 2 \\
\hline \multicolumn{2}{|l|}{ Eseményleírás } & 16 & - \\
\hline \multirow{2}{*}{\multicolumn{2}{|c|}{ Összesen }} & 31 & 13 \\
\hline & & \multicolumn{2}{|r|}{44} \\
\hline
\end{tabular}

Az első változót illetően az általánosított szervezési kérdések, metodológiai leírások és a formátumban rejlő lehetőségek tárgyalása alkotják az első fő megközelítési csoportot. A második megközelítés a formátumban azonosított lehetőségekre fókuszál. Az ezt a megközelítést alkalmazó cikkek két élesen elkülöníthető csoportra oszthatók, amely már önmagában jelzi, hogy melyek a hackathon-formátumú eseményekben rejlő fő várt és észlelt értékek: (1) a hackathon folyamán kidolgozott megoldások az előre definiált problémára, és (2) az esemény nyújtotta haszon a résztvevők számára.

Ennek megfelelően a módszertan lehetőségeit vizsgáló cikkek egyrészt az eseményeken született tervek gyakorlati megvalósítását (a termékeket) vizsgálják. (Ezt a kérdést kétféleképpen közelítették meg a vizsgált cikkek: adott hackathonokon kidolgozott megoldások követése és azok megvalósulásának vizsgálata, valamint a már megvalósult, hackathonokra visszavezethető termékek bemutatása.) A második a megközelítéssel, a résztvevők által élvezett haszonnal összefüggésben a bővülő tudásanyag, valamint a különböző készségek erősítése és a kapcsolati háló bővítésének lehetősége merült fel.

A harmadik, leggyakrabban használt megközelítésnek az egyes események deskriptív bemutatása bizonyult. Ezek a cikkek, bár tartalmazhatnak az előző két témával összefüggő megállapításokat, nem feltétlenül törekszenek általános szabályok és javaslatok, valamint empirikus bizonyítékokon alapuló kijelentések megfogalmazására azokkal kapcsolatban.

Egészségügyi hackathon szervezésére már Magyarországon is volt példa. 2017-ben az EMK, az Óbudai Egyetemmel közösen rendezett egy hasonló eseményt [3], melynek fókuszában szintén egy komoly egészségügyi-társadalm probléma, a dohányzás, és annak visszaszorításáért való küzdelem állt $[4,5]$. Ennek ellenére, a hazánkban egészségügyi területen szervezett hackathonokkal foglalkozó munkák még hiányoznak. A Magyar Tudományos Múvek Tára csupán kettő hackathonokkal foglalkozó cikket tartalmaz, és ezek egyike sem az egészségügyi területtel van összefüggésben [6]. A jelen munka elsősorban ezt a hiányt szeretné pótolni, tekintve, hogy itthon is nagy mennyiségü tapasztalat gyült már össze a témában. Célja a téma bevezetése a magyar szakirodalomba, egy esettanulmány (egy már lezajlott egészségügyi hackathon) bemutatásán keresztül illusztrálva a megközelítésben rejlő lehetőségeket és az esemény lebonyolításának menetét.

A bevezetőben felvázolt probléma és a szakirodalomban azonosított tendenciák nyomán három célt tủztünk ki az eseménynek: (1) olyan ötletek gyuujtése, amelyek hozzájárulhatnak a COVID-19 oltási hajlandóság növeléséhez; (2) másodszor, egyedi megközelítések, és innovatív megoldások bátorítása; (3) a multidiszciplináris együttmüködés támogatása, a különböző tudományterületeknek a probléma megoldásához nyújtott hozzáadott értékének kiaknázása.

\section{ESETTANULMÁNY - HACKATHON A GYAKORLATBAN}

Az „Oltáskampány - Te hogy csinálnád?” címet viselő hackathont a járványhelyzetre való tekintettel online szervezte meg a Magyar Egészségügyi Menedzsment Társaság (MEMT), és a Semmelweis Egyetem Egészségügyi Menedzserképző Központ (EMK), a Magyar Tudományos Akadémia Fenntartható Fejlődés Elnöki Bizottsága, az Egészségügyi Világszervezet (WHO) és az Innovációs és Technológiai Minisztérium (ITM) támogatásával, 2021. december 10. és 11. között, magyar nyelven. A megoldandó probléma („Challenge”) a következőképp lett megfogalmazva:

„Mindenki meggyőzhető! Készítsetek innovatív, megvalósítható stratégiát a COVID-19 oltási hajlandóság növelésére. A stratégia célozhatja a teljes lakosságot vagy egy meghatározott célcsoportot, és a választott intézkedésforma is teljesen rátok van bízva (lehet kommunikációs stratégia, politikai beavatkozás...).

A versenyformátumú eseményen a résztvevőknek négyfös csapatokban, meghatározott idő alatt (körülbelül 24 óra) kellett kidolgozni egy megoldási javaslatot erre a problémára, amelyet egy 2500-3000 karakteres absztraktban kellett összefoglalni, illetve egy 3 perces „pitch”-ben (rövid, tömör, 
meggyőzést célzó előadás) bemutatni a szakértőkből álló zsüri előtt.

\section{JELENTKEZÉS}

Az eseményre való regisztrációt egyetemi hallgatók számára nyitottuk meg. Egy online regisztrációs lap kitöltésével lehetett jelentkezni négyfős csapatban vagy egyénileg. A regisztrációs időszakban a versenyt a különböző egyetemi kommunikációs csatornákon (például hallgatói önkormányzatok), illetve online (közösségi) médiában hirdettük. A viszszajelzések alapján a jelentkezők többsége $(70,6 \%)$ az előbbi útján értesült az eseményről. Ezt követi az ismerősi ajánlás (21,6\%), és az online média (7,8\%). A jelzett határidőig 109 jelentkezést regisztráltunk (28 csapat). Az online formátumnak köszönhetően Magyarországon túl Romániából, Hollandiából és az Egyesült Királyságból is képviseltették magukat hallgatók, így összesen 4 országból és 15 különböző egyetemröl érkeztek jelentkezések. A multidiszciplinaritás (a fent megfogalmazott harmadik cél) már ebben a fázisban erősen megjelent, hiszen az egészségügybe tartozó tudományterületek (orvos, fogorvos, gyógyszerész, közegészségügyi szakember) mellett többek között műszaki, jogi, gazdasági és kommunikációs területekről is regisztráltak hallgatók. Ezen túl, a képzési szintekben is láttunk diverzitást, az alapmester- és osztatlan képzések mellett doktori képzések hallgatói is voltak a jelentkezők között.

\section{A SZERVEZÉS, A VERSENYZÖK TÁMOGATÁSA}

Már a versenyt megelőzően törekedtünk a hatékony, többfrontos kommunikációra a jelentkezőkkel. A résztvevői tudnivalókat - praktikus információkat, versenyszabályzatot, az online platform használatát bemutató kisokost - emailben juttattuk el a jelentkezőkhöz. Emellett létrehoztunk egy zárt csoportot az egyik ismert közösségi oldalon, ahol a belépett jelentkezők szintén megtalálhattak minden tudnivalót és bármikor kérdezhettek a szervezőcsapattól. Akiktől egyik platformon sem kaptunk visszajelzést, azokkal a regisztrációnál megadott telefonszámon léptünk kapcsolatba. A résztvevőkkel ezeken a csatornákon az esemény alatt is folytattuk a kommunikációt. Továbbá a verseny online platformjának megnyitásával, annak közös üzenőfalával és személyes üzenetküldő lehetőségével is kiegészültek a szervezők és versenyzők közötti kapcsolattartás lehetőségei. A résztvevők is többféleképpen el tudták érni a szervezőket kérdés, vagy probléma esetén, így biztosítva a versenyzők folyamatos támogatását. (A versenyzők részéről a legnépszerübb kommunikációs felületnek az online platform chat felülete bizonyult.) Ezen túl a közérdekủ információkat (az aktuális megjegyzendő időpontokat, határidőket) képernyőmegosztással tettük folyamatosan elérhetővé az online platform közös terében (1. ábra). Az ábrán látható vizuális elemek visszaköszöntek a kivetített kommunikációban és a szervezők videóháttereiben is, segítve az egységes megjelenést és azonosithatóságot.

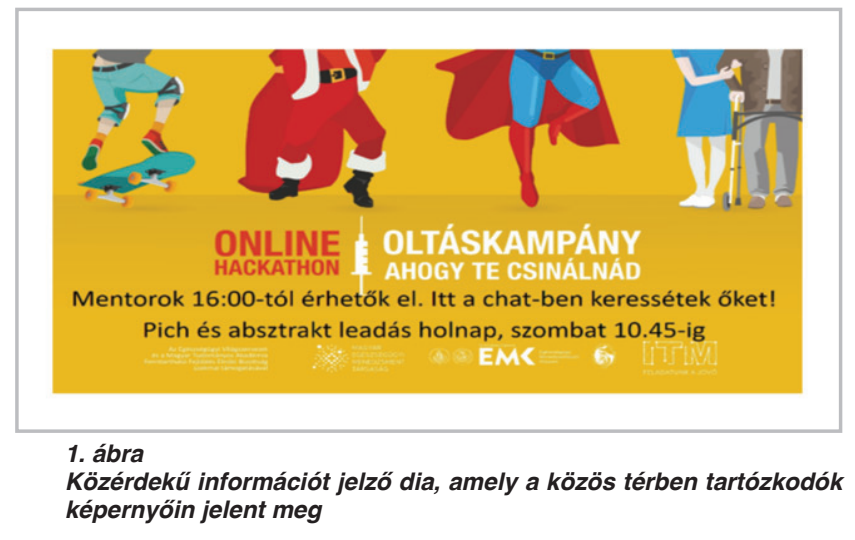

A Hackathon központját az Egészségügyi Menedzserképző Központban rendeztük be, három helyiségben: (1) A „broadcast szoba”, ahol az online platformot futtató számítógép kapott helyet, illetve ahol a szervezők megbeszéléseket tarthattak és az esemény közben felmerülö feladatokat végezhették el (például az online platform kezelése és felügyelete, a mentorkonzultációk koordinálása vagy a csapatok beosztása előzsűri-csoportokba - lásd lejjebb). (2) A stúdió, ahonnan a két konferáló munkatárs tudott csatlakozni; (3) A szervezői szoba, ahol szintén az esemény közben felmerülő feladatokon tudtak dolgozni a munkatársak, többek között a (vizuális) információs anyagok készítésén, a kapcsolattartáson, a versenyzők támogatásának biztosításán több platformon, valamint a projektadatok kezelésén (azok védelmének biztosításával).

\section{LEBONYOLÍTÁS}

A résztvevők december 10-én pénteken 9:00-tól csatlakozhattak az eseményhez, az elöre megadott linken. Az érkezőket megkértük, hogy teljes nevükkel és egyetemi karuk rövidítésével szerepeljenek az online platformon. A köszöntés és a bevezető eligazítás, programismertetés után a verseny 5 különböző blokkból épült fel.

Az első blokk - péntek 9:30 és 11:00 között - a gondolatébresztést, a probléma bemutatását és körbejárását, valamint a versenyzők inspirálását célozta a munka megkezdése előtt. Hat szakértőt kértünk fel előzetesen rövid, 10-15 perces előadások megtartására.

Az előadások menetrendje a 2. táblázatban látható. „Icebreaker" gyanánt az előadókat hivatalos titulusaik mellett személyes „fun fact”-ek (érdekes, meglepő információ az

\begin{tabular}{|c|c|c|}
\hline $\begin{array}{l}\text { Dr. Gaál } \\
\text { Péter }\end{array}$ & \begin{tabular}{|l|}
$\begin{array}{l}\text { elnök, Magyar Egészségügyi } \\
\text { Menedzsment Társasáá }\end{array}$ \\
\end{tabular} & Megnyitó, köszöntõ \\
\hline \begin{tabular}{|l|} 
Dr. Szócska \\
Miklós
\end{tabular} & $\begin{array}{l}\text { igazgató, Egészzégūgyi } \\
\text { Menedzserképzō Kozpont }\end{array}$ & $\begin{array}{l}\text { Az oltási hajlandóság nôvelését célzó innovatív, } \\
\text { multidiszciplináris meakózelitésekben reilō lehêốséaek }\end{array}$ \\
\hline $\begin{array}{l}\text { Dr. Szigeti } \\
\text { Szabolcs }\end{array}$ & országiroda vezetô (WHO) & Oltásellenes aktivizmus \\
\hline \begin{tabular}{|l|} 
Prof. \\
Szathmáry \\
Eörs
\end{tabular} & \begin{tabular}{|l|} 
elnök, Magyar Tudományos \\
Akadémia, Fenntartható \\
Feilódés Elnoki Bizottság
\end{tabular} & $\begin{array}{l}\text { Ókológiai változások és kórokozók - A járványok } \\
\text { lehetséges alakulása a jovốben }\end{array}$ \\
\hline Toth Dóra & $\begin{array}{l}\text { MEMT szakértō, Hackathon } \\
\text { szervezố }\end{array}$ & $\begin{array}{l}\text { Hackathon-Aktuális komplex problémák } \\
\text { megoldásának versenve }\end{array}$ \\
\hline $\begin{array}{l}\text { Dr. Lakatos } \\
\text { Botond }\end{array}$ & $\begin{array}{l}\text { A Dél-pesti Centrumkórház } \\
\text { infektológus fôorvosa }\end{array}$ & A SARS-CoV2 okozta betegség \\
\hline
\end{tabular}

2. táblázat

Az elsö blokkban elhangzott elöadások 
adott személyröl) megosztásával konferáltuk fel. Az előadók közül Szathmáry Eörs nem tudott személyesen bekapcsolódni az eseménybe ebben az időpontban, az ő videón előre rögzített előadását a szervezők játszották le a résztvevőknek. Mivel több résztvevő jelezte, hogy egyéb kötelezettségek miatt szintén nem tud majd csatlakozni az eseményhez péntek délelőtt, az előadásokat rögzítettük és a felvételeket (valamint az előadáshoz használt bemutatókat) a blokkot követően megosztottuk az összes résztvevővel.

Az előadásokat a második blokk, a csapatmunka követte. Végül a 28 csapatnyi jelentkezőből 25 csapat vett részt a versenyen. Ezek közül hármat állítottunk össze egyéni jelentkezőkböl, a többiek csapatként jelentkeztek. Az egyéni jelentkezők csapatokba osztásánál az esemény harmadik célkitűzése alapján a multidiszciplinaritást tartottuk szem előtt. A szükséges beosztások kihirdetése után megnyitottuk a csapatok közös munkáját lehetővé tevő „személyre szóló” szobákat, a következőképp: minden csapathoz, a csapatnév mellett (amelynek kitalálására megkértük az újonnan, egyéni jelentkezőkből alakult csapatokat is) rendeltük egy számot (1-től 25-ig). Ez a szám megegyezett a személyes szoba számával. A szobákat a közös eseményen belül nyitottuk meg, így minden versenyző kiválaszthatta a számára kijelölt szobát, és beléphetett oda. (Amennyiben ki akart lépni a szobából, a versenyző a közös térbe került vissza, nem hagyta el a platformot.). A résztvevők tetszöleges alkalommal léphettek be a szobákba (illetve ki a szobákból), ameddig a szervezők nyitva tartották azokat. Ez a megoldás lehetőséget biztosított a szervezők szempontjából a csoportmunkák hatékony megszervezésére és koordinálására, valamint a csapatok szempontjából a (lehetőségekhez mérten) zavartalan közös munkára.

Be-, illetve kilépésnél felmerülő probléma esetén a szervezők központilag is a megfelelő szobába tudták tenni az adott résztvevőt, illetve figyelemmel tudták kísérni, ki melyik szobában tartózkodik. Mivel előfordult, hogy a csapatok közösen, egy eszközröl jelentkeztek be az eseményre, számos szoba üresen maradt (hiszen, ha a tagok fizikailag egy légtérben vannak, nincs szükségük a virtuális szobára a közös munkához). Ezért a csoportmunkablokk ideje alatt fontos volt felhívni az üres szobákba tartozó versenyzőket, hogy ellenőrizzük, valóban dolgoznak-e a projektükön. Minden felhívott versenyző megerősítő választ adott.

A csapatmunka-blokk 12:00-től 16:00-ig tartott. Az ötletelés és a közös munka megkezdése az egyéni jelentkezőkből alkotott csapatok esetén ismerkedéssel egészült ki. Ezt a 3. blokk, a mentorálás időszaka követte, hivatalosan 16:00 és 18:00 óra között. A mentorok különböző, a versenyzők projektjei szempontjából releváns területek szakértői, akik a csapatok kérésére rövid konzultációk formájában tanácsot, segítséget nyújtottak a projekt elkészítéséhez. A résztvevő mentorok listáját és szakterületeiket a 3 . táblázat mutatja. A multidiszciplinaritás jegyében a mentorok is számos szakterületet képviseltek. Fontos kiemelni, hogy a bár mentorok többsége mindkét mentorblokkban elérhető volt (a péntek 16:0018:00 közötti idősáv mellett a másnapi 9:00-11:00 közötti idő-

\begin{tabular}{|c|c|c|}
\hline & Mentor & Kompetencia \\
\hline Dr. Kulja András & $\begin{array}{l}\text { Orvos, sebész rezidens, 2021-ben } \\
\text { az év COVID orvosa }\end{array}$ & Social media kommunikáció \\
\hline $\begin{array}{l}\text { Dr. Davidovics } \\
\text { Krisztina }\end{array}$ & Jogász (EMK) & Jogi kérdések \\
\hline $\begin{array}{l}\text { Alpern Linda, } \\
\text { Fejér-Székely Anna }\end{array}$ & $\begin{array}{l}\text { Vizuális egészségügyi } \\
\text { kommunikációs szakemberek (EMK, } \\
\text { Semmelweis Eqvetem) }\end{array}$ & Grafika, design \\
\hline Bese Nóra & $\begin{array}{l}\text { Kommunikációs igazgató (Bethesda } \\
\text { Gyermekkorház) }\end{array}$ & Egészségügyi kommunikáció \\
\hline Dr. Stubnya Bence & $\begin{array}{l}\text { Phd hallgató, elnök (Doktorandusz } \\
\text { Önkormányzat) }\end{array}$ & Vállalkozói szemlélet \\
\hline Joó Tamás & $\begin{array}{l}\text { Közgazdász, okleveles } \\
\text { egészségpolitikai szakértö, } \\
\text { elnökhelyettes (MEMT) }\end{array}$ & $\begin{array}{l}\text { Közgazdaságtan, } \\
\text { projektszemlélet, } \\
\text { változtatásmenedzsment }\end{array}$ \\
\hline Füzes Nóra & Pszichológus, (Ludovica Collegium) & Pszichológia \\
\hline Németh Franciska & $\begin{array}{l}\text { Ápoló, Influenszer, kommunikációs } \\
\text { szakember }\end{array}$ & Social media kommunikáció \\
\hline Dr. Szócska Miklós & Igazgató (EMK) & Egészségpolitika \\
\hline
\end{tabular}

3. táblázat

A mentorok és az általuk képviselt tudományterületek listája

sávban is) előfordult az is, hogy egy mentor egyéb kötelezettségek miatt csak az egyik időszakban tudott a versenyzők rendelkezésére állni. Azt, hogy melyik mentor mikor áll majd a csapatok rendelkezésére, több platformon jeleztük nekik, illetve a mentorok megérkezéséről valós időben tájékoztattuk a külön szobában dolgozó csapatokat.

A mentorokkal való konzultáció nem követelmény, hanem lehetöség volt, a csapatok eldönthették, melyik mentor segítségét szeretnék kérni. Ezután a csapat egyik tagja visszalépett a saját szobájából a közös térbe, és annak üzenöfalán jelezte, melyik szobában, melyik mentorral/mentorokkal szeretnének konzultálni. Végül az üzenetvivő visszalépett a saját szobájába, folytatta a munkát és várta a kért mentor megérkezését. Amennyiben a mentor éppen elérhető volt, csatlakozott a megjelölt szobához. Ellenkező esetben a szervezők egy táblázatban jegyezték a beérkezett kérelmet, és amint a mentor végzett az éppen aktuális konzultációval, és visszalépett a közös térbe, a feljegyzett kérések alapján a következőbe irányították. A pénteki mentoridő végül a mentorálási kérések mennyiségének, illetve a mentorok elérhetőségének köszönhetően hosszabb lett a tervezettnél, fél nyolckor zárult le. (Volt mentor, aki azért ajánlotta fel, hogy tovább marad, mert másnap már nem tudott a versenyzők rendelkezésére állni.) A mentoridő végén nem zártuk le a hackathon platformját, megadtuk a lehetőséget a versenyzőknek, hogy éjszaka azon, a kijelölt szobáikban folytassák a munkát. Csupán arra kértünk mindenkit, hogy másnap 9:00-ig csatlakozzanak (újra) az eseményhez, ugyanazon a linken.

A második napon 9:00-tól volt ismét lehetőség a mentorok segítségének igénybevételére, egészen 11:00-ig a fent leírt módon. A 11 órás határidő a projekt kidolgozásának a végét is jelentette, ekkorra kellett ugyanis elküldeni a kész absztraktot és a pitch-et kísérő prezentációt a szervezők által megadott email címre. Minden csapat időben megküldte a kért absztraktot és prezentációt.

A projektmunka lezárását követően megkezdődött az esemény negyedik blokkja, a háromperces „pitch”-ek bemutatása. A csapatok nagy száma miatt elődöntőket is szervez- 
tünk: a 25 csapatot három "előzsűri-csoportba" osztottuk (két előzsüri 8 csapatot, egy pedig 9 csapatot értékelt). A beosztás nagyrészt véletlenszerüen történt, csupán két megfontolás volt meghatározó: (1) az előzsűri tagjai és a versenyzők közötti családi kötelékből adódó összeférhetetlenség elkerülése; (2) annak elkerülése, hogy Dr. Szócska Miklós - aki pénteken mentorált, és az egyik előzsűri tagja is - azokat a csapatokat értékelje az elődöntőben, akik az ő segítségét kérték a mentoridőben. A háromfős előzsűrik összeállításánál arra figyeltünk, hogy mindegyikben legyen legalább egy olyan értékelő, aki a döntő „főzsűrijének” is tagja, annak érdekében, hogy egyik csapatot se ejtse ki olyan előzsűri, amely nem képviselteti magát a „végső döntés” meghozatalában. Az előzsűrik és a „főzsűri” összetétele a 4. táblázatban látható. Minden (elő)zsűritag előre megkapta a „pitch”-ek értékelésének szempontjait és a blokk megkezdése előtt az értékelőlapokat is. Az értékelés szempontjai a következők voltak: az ötlet újdonsága, innovációs értéke és megvalósíthatósága, valamint a kihívásra kínált megoldás minősége, a prezentáció design-ja és a „pitch” meggyőző ereje.

\begin{tabular}{|c|c|c|}
\hline & & Zsüritagok listajja \\
\hline \multirow{3}{*}{$\begin{array}{c}\text { Elözsū } \\
1\end{array}$} & Dr. Szigeti Szabolcs & országirioda-vezetổ (WHO) \\
\hline & Dr. Purebl György & igazgató (Semmelweis Egyetem Magatartástudományi Intézet) \\
\hline & Farkas Beáta & szakértö (MEMT) \\
\hline \multirow{3}{*}{$\begin{array}{l}\text { Elözsürí } \\
\|\end{array}$} & Dr. Szócska Miklós & igazgató (EMK) \\
\hline & habil. Koós Pál & $\begin{array}{l}\text { Ooktatásért felelō̄s rektorhelyettes, BA szakfelelös (Moholy-Nagy } \\
\text { Müvészeti Eqvetem) }\end{array}$ \\
\hline & Aszalós Zoltán & szakértō (MEMT), Hackathon szervezō \\
\hline \multirow{3}{*}{$\begin{array}{c}\text { Elözsū } \\
\text { III }\end{array}$} & Dr. Charaf Hassan & $\begin{array}{l}\text { dékán (Budapesti Müszzki Egyetem, Villamosmérnöki és } \\
\text { Informatikai Kar) }\end{array}$ \\
\hline & Dr. Gaál Péter & elnök (MEMT) \\
\hline & Kovács Réka & szakértō (MEMT), Hackathon szervezō \\
\hline \multirow{8}{*}{$\begin{array}{l}\text { Döntō } \\
\text { zsüri }\end{array}$} & Prof. Szathmáry Eörs & $\begin{array}{l}\text { elnök (Magyar Tudományos Akadémia Fenntartható Fejlodós } \\
\text { Elnöki Bizottsáq) }\end{array}$ \\
\hline & Dr. Szigeti Szabolcs & országiroda-vezetô (WHO) \\
\hline & Csiki Gergely & lapigazgató (portfolio.hu) \\
\hline & Dr. Lakatos Botond & $\begin{array}{l}\text { fôorvos (Dél-pesti Centrumkórház Infektológiai Oszzály) oktató } \\
\text { (Semmelweis Eavetem) }\end{array}$ \\
\hline & Dr. Charaf Hassan & $\begin{array}{l}\text { dékán (Budapesti Müszaki Egyetem, Villamosmérnöki és } \\
\text { Informatikai Kar) }\end{array}$ \\
\hline & habil. Koós Pál & $\begin{array}{l}\text { oktatásért felelös rektorhelyettes, BA szakkelelōss (Moholy-Nagy } \\
\text { Mävészett Eqvetem) }\end{array}$ \\
\hline & $\begin{array}{l}\text { Prof. Dr. Bódis } \\
\text { József }\end{array}$ & $\begin{array}{l}\text { felssōoktatásért, innovácioért és szakképzésért felelös államtitikár, } \\
\text { (ITM) }\end{array}$ \\
\hline & Dr. Szócska Miklós & |igazgató (EMK) \\
\hline
\end{tabular}

\section{4. táblázat}

A zsưritagok beosztása az elözsürikbe és a döntő zsüribe

Az elődöntök megtartására a csapatmunkákhoz hasonlóan külön szobákat alakítottunk ki. A csapatok, illetve az előzsűri tagjai beléptek a jelzett szobába, ahol előbbiek sorban bemutatták projektjeiket az értékelőknek (és versenyzőtársaiknak). Mivel a tömörség kiemelten fontos a „pitch”-ek esetében, az előzsűri valamelyik tagja (vagy az egyik előzsűri esetében az egyik szervező, aki facilitátorszerepet töltött be) mérte a bemutatók idejét, és leállította az előadást három percnél. Az egyes előadások után az előzsűri maximum három kérdést tehetett fel, amelyekre a csapattól rövid vála- szokat vártak. Az összes „pitch” bemutatását követően a versenyzők elhagyták a kijelölt előzsűri szobát és visszaléptek a közös térbe. Az előzsűri tagjai rövid tanácskozás után eldöntötték, hogy az adott elődöntőből melyik négy csapat jusson a döntőbe.

A döntőbe jutott 12 csapat listája 13:00-kor került kihirdetésre. A 12 továbbjutott csapat ezután 13:00 és 14:00 óra között adta elő ismét háromperces „pitch”-ét ezúttal a közös térben, a főzsűri (és versenyzőtársaik) előtt. Az előzsűrihez hasonlóan a zsűritagok az egyes előadások után maximum három kérdést tehettek fel.

A 12 döntőbe jutott csapatból 4 hiteles információ átadására célzottan alkalmas új internetes platformot álmodott meg. A hiteles információ közlése további 7 csapat tervében jelenik meg kiegészítő elemként, ezeknél azonban máshol van a hangsúly. Van, ahol a stratégia egymás meggyőzésére motivál (2 csapat), vagy alacsony átoltottságú kistelepüléseket céloz oltóbuszokkal (2 csapat). Utóbbi 4 csapatnál a megoldás részeleme valamilyen materiális ösztönzési forma (ajándékok, pénzjutalmak, kedvezmények). A döntőbe jutott tervek között van, ahol a fő cél kifejezetten a fiatalok megszólítása a közösségi oldalakon, vagy egy új brand létrehozásával, míg egy másik döntős csapat egy intézkedéscsomag bevezetését javasolta, amely a szervdonáció esetében kiépített opt-out rendszert alkalmazná a COVID-19 oltásra. Szintén döntős lett annak a csapatnak az ötlete, amely virtuális valóságélmény keretében mutatná be az oltatlanság lehetséges negatív következményeit, ezzel ösztönözve az oltásra.

\section{EREDMÉNYEK, DÍJAZÁS}

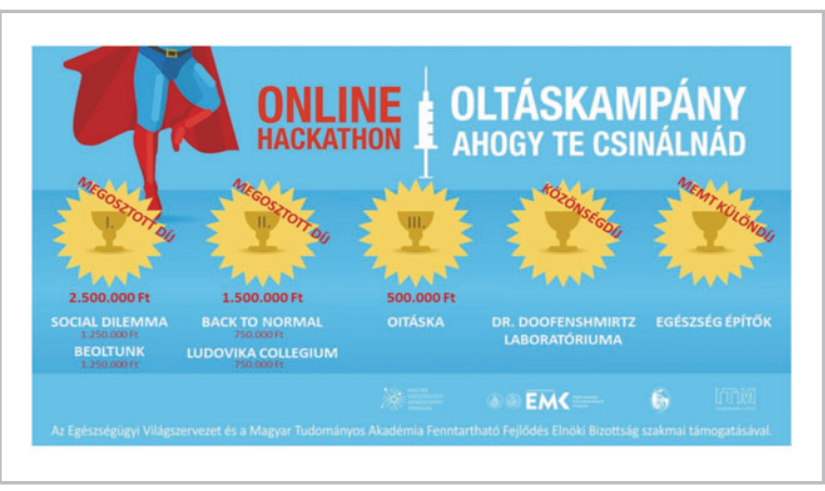

\section{2. ábra \\ A kiosztott dijak}

A „pitch”-ek befejeztével a zsűri „elvonult” egy külön szobába, ahol egyórás tanácskozást követően 15:00-kor hozta meg a döntését. Ezzel megkezdődött az esemény ötödik, záró blokkja, az eredményhirdetés. Az I. II. és III. helyezéseken kívül, - amelyeket a zsűri ítélt oda - két díj került kiosztásra: a MEMT különdíjat az elődöntőben kiesők közül a legjobbnak ítélt csapat kapta (ez még a döntő megkezdése előtt kiosztásra került) és egy közönségdíj, amely egy online szavazó platformon, (amelyet az esemény üzenőfalán osztottunk 
meg) a versenyzőktől legtöbb szavazatot kapott előadásnak lett odaítélve. Elöbbit az „Egészséget építünk” nevű csapat nyerte, akik egy Nemzeti Egészségkártya program keretében juttatnák anyagi támogatáshoz az oltás mellett döntőket. Utóbbit a „Dr. Doofenshmirtz laboratóriuma” kapta. Ők egy új, oltással összefüggő „brand”-et építenének, amely elsősorban a fiatalokat szólítaná meg.

A zsűri a III. helyet az „OITáska” tagjainak ítélte oda, akik szintén a fiatalokat céloznák, elsősorban különböző közösségimédia-platformok használatával. A bírálók döntése alapján a II. helyen két csapat osztozik: a „Back to Normal”, akik egy, az ismerősök meggyőzésére motiváló nyereményjátékkal kiegészített videóinformációs oldallal növelnék az oltási kedvet, és a "Ludovica Collegium”, akik kifejezetten hátrányos helyzetú településeket céloznának oltóbuszokkal, amelyeket szórakoztató elemekkel és ajándékokkal tennének vonzóbbá. Végül az I. helyezés szintén megosztva került kiosztásra. Az egyik nyertes, a „Social Dilemma” nevű csapat, a meggyőzhető városi lakosságot célozná virtuálisvalóságeszközökkel, míg a másik győztes, a „Beoltunk” egy, az ismerősök meggyőzésére kedvezménykuponokkal motiváló internetes platformot hoznának létre.

A dijjazottak pénzjutalomban részesültek, amelyhez az ITM és a WHO biztosította az anyagi forrást. A harmadik helyezett csapat $500000 \mathrm{Ft}$ pénzjutalomban részesült, a második helyezettek 750 000-750 000 összesen 1500000 Ft díjat kaptak, míg az első helyezettek 2500000 Ft-on osztoztak meg (2. ábra). Az esemény végül a nyertes csapatok felszólalásával, élményeik és köszönetük megosztásával zárult le. A platformot még nyitva hagytuk egy ideig, arra az esetre, ha a versenyzők ismerkedésre, kapcsolatépítésre használnák azt.

\section{KÖVETKEZTETÉS}

A fentiek alapján elmondható, hogy a hackathon mindhárom, előzetesen kitǔzött célt teljesítette: (1) Számos olyan ötlet gyűlt össze, amelyek hozzájárulhatnak a COVID-19 oltási hajlandóság növeléséhez. (2) Több egyedi megközelítés, és innovatív megoldás jelent meg a „pitch”-ekben. (3) A tanulmányokat tekintve sokszínű csapatok közös munkája nyilvánvalóvá tette, hogy az interdiszciplináris együttmüködés, valamint különböző tudományterületek együttes mozgósítása komoly értéket jelenthet a célzott problémamegoldásában.

Összességében, az esemény sikere három szinten igazolta a hackathon módszertan hatékonyságát: egyrészt mint olyan eseményt, amelyet meg lehet tartani teljes mértékben virtuálisan, úgy, hogy közben értékes maradjon. Másodszor, mint olyan eszközt, amely képes megmozgatni különbözö hátterü fiatalokat, így elősegítve az innovatív gondolkodást és problémamegoldást az egészségügy területén. Harmadrészt, figyelembe véve, hogy a vakcinák kiemelten fontos eszközei a fertőző betegségek elleni védekezésnek, ezáltal pedig kiemelt egészségbiztonsági jelentőséggel bírnak [7], a fent bemutatott hackathon arra is rámutatott, hogy a metodológia jól alkalmazható egészségbiztonsági kockázatok kezeléséhez szükséges stratégiák generálásához. Így tehát egy hackathon formátumú esemény hozzájárulhat egy rugalmas, a jövő kihívásaira hatékonyan válaszolni képes magyar egészségügyhöz.

A metodológiát célzó további magyar kutatások, különösen a résztvevők tapasztalatainak feltárása, és az ő szemszögükből jelentkező értékek bemutatása mélyíthetik a hackathonnal és annak előnyeivel kapcsolatban itt levont következtetéseket.

\section{IRODALOMJEGYZÉK}

[1] DePasse JW, Carroll R, Ippolito A et al.: Less noise, more hacking: how to deploy principles from MIT's hacking medicine to accelerate health care. Int J Technol Assess Health Care. 2014 Jul;30(3):260-4. doi: 10.1017/S0266462314000324. Epub 2014 Aug 6. PMID: 25096225.

[2] National Library of Medicine: Search Results to "(hackathon[Title/Abstract]) AND (health[Title/Abstract])", 2022, https://pubmed.ncbi.nlm.nih.gov/?term=\%28hackathon\%5BTitle\%2FAbstract\%5D\%29+AND+\%28healt h\%5BTitle\%2FAbstract\%5D\%29\&sort=\&filter=simsearch1. fha\&size=200. (Letöltve: 2022. 01. 05.)

[3] Óbudai Egyetem: vITathon, 2017. https://uni-obuda. hu/video/vitathon-2017/ (Letöltve: 2022. 01. 27.)
[4] Szócska M, Joó T, Vokó Z et al.: A dohányzás elleni küzdelem a 2010-2014 közötti időszakban, IME, 2017, 16(10) 11-17 (Letöltve: 2022. 01. 27.)

[5] Palicz T, Szócska M, Joó T: A népegészségügyi termékadó dohánytermékekre való kiterjesztésének lehetősége, IME, 2018, 17(7) 30-33 (Letöltve: 2022. 01. 27.)

[6] Magyar Tudományos Művek Tára: „keresőszó: hackathon", 2022 https://m2.mtmt.hu/gui2/?mode=search\& query=publication;labelOrMtid;eq;hackathon (Letöltve: 2022. 01. 05.)

[7] Szócska M, Joó T. Health Security Issues. In: Finszter G. \& Sabjanics I. (eds) Security Challanges in the 21st Century. Springer. 2018. pp. 335-347. DOI: 10.1007/978-3-319-51761-2_25-1 


\section{A SZERZŐK BEMUTATÁSA}

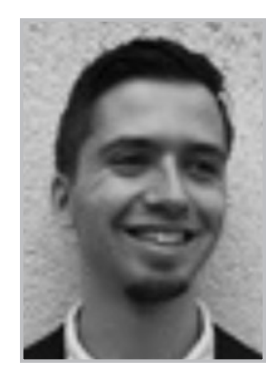

Varga Gergely egészségbiztonsági kérdésekre koncentráló kutató, 2021 szeptembere óta a Semmelweis Egyetem Egészségbiztonsági és Kibervédelmi Tudásközpontjának munkatársa. Diplomáját 2021-ben szerezte a Paris School of International Affairs mester-

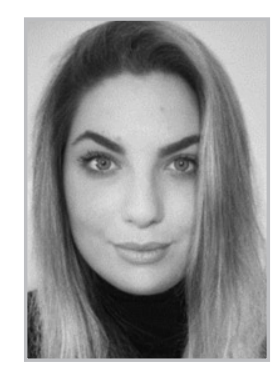

Tóth Dóra junior egészségügyi innovációs szakértő. Tanulmányait a Semmelweis Egyetem Közszolgálati Karán végezte. Már egyetemi évei alatt elkezdték érdekelni a népegészségügyi programok és az egészségügyi szervezés, ezért főszervezőként részt vett 6 sikeres egészségügyi szűrőprogram-

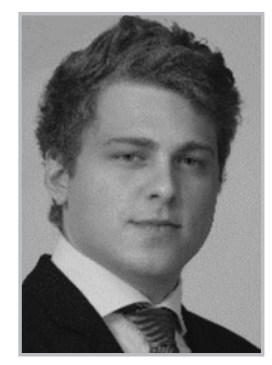

Mikesy Gergely 2019-ben általános orvosként végzett a Semmelweis Egyetemen. Diploma után a Semmelweis Egyetem Egészségügyi Közszolgálati Karán tanult, Egészségügy Menedzsment szakon. Eközben a Semmelweis

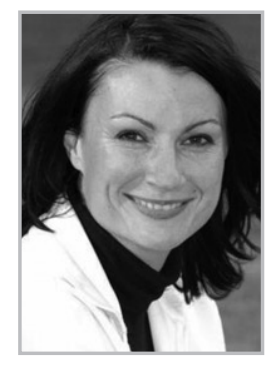

Makai Marianna marketingvezető szakközgazdász. A MOL-csoportnál töltött 10 éves munkaviszonyát a Kutatásiés Termelési Üzletág PR munkatársaként kezdte, és a teljes társaság, valamint a részvénytársasággá alakuláshoz kapcsolódó belső kommunikációs fejlesztés motorjaként fejezte be. A Magyar Postánál kommunikációs mene-

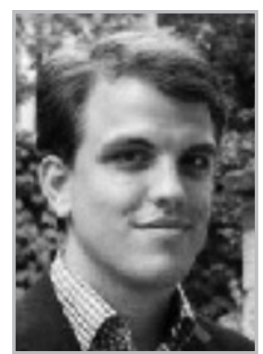

Joó Tamás közgazdász, okleveles egészségpolitikai szakértő és elektronikus információbiztonsági vezető. 2011 2016 között kutatóként, gazdasági elemzőként, illetve projektvezetőként az államigazgatás különböző szintjein dolgozott. Több hazai és nemzetközi WHO projekt, valamint fejlesztés irányítója és képzésén, Global Health specializációval. Korábban kutatóként közreműködött a Human Development Research Initiative „Global Health” kutatócsoportjában, a Francia Vöröskereszt munkájában, valamint az Egészségügyi Menedzserképző Központ COVID-19 elleni vakcinákkal foglalkozó munkacsoportjában.

ban Kárpátalján. 2019 óta dolgozik az Egészségügyi Menedzserképző Központban mint szakmai projektkoordinátor több egészségügyi EU projektben. Emellett főszervező a tavaly indult Egészségpart nevű átfogó egészségügyi szűrőprojektben, valamint részt vesz a projektmenedzsment oktatásban és nagy tapasztalattal rendelkezik Hackathon rendezvények szervezésében és lebonyolításában is.

Egyetem Egészségügyi Menedzserképző Központjában kezdett dolgozni szakértőként. Legfontosabb tématerületei a betegbiztonság, a népegészségügy, a prevenció, ezeken belül is a digitális megoldások alkotják a fő fókuszt. Több hazai, valamint nemzetközi projekt szakmai és menedzsment szintű előkészítésében, valamint vezetésében vett részt.

dzserként dolgozott, ahol a 2007-ben alakuló Postás Egészségpénztár kommunikációs vezetői feladatával bízták meg. 2012-től az OTP Bank médiakommunikációs csapatában szakértőként főként új, egyedi projekteket dolgozott ki és menedzselt. A Nemzeti Mobilfizetési Zrt. 2014-es megalakulásától kezdve irányította a társaság kommunikációs tevékenységét. A Semmelweis Egyetem Egészségügyi Menedzserképző Központ kommunikációs vezetője 2017-től.

résztvevője. 2014-től a Semmelweis Egyetem, Egészségügyi Menedzserképző Központjának senior egészségügyi közgazdászaként hazai és nemzetközi finanszírozású projektek elökészítésében és végrehajtásában vesz részt. Különböző digitális egészségüggyel, adattudománnyal, mesterséges intelligenciával, ipari befolyásolási technikákkal, egészségbiztonsággal és kibervédelemmel kapcsolatos területeken végzi kutatási és oktatási feladatait. 